International Journal of Current Advanced Research

ISSN: O: 2319-6475, ISSN: P: 2319 - 6505, Impact Factor: SJIF: 5.995

Available Online at www.journalijcar.org

Volume 6; Issue 3; March 2017; Page No. 2808-2810

DOI: http://dx.doi.org/10.24327/ijcar.2017.2810.0111

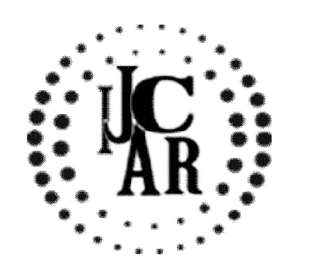

Research Article

\title{
REVIEW ARTICLE ON BELIEFS AND MYTHS OF PEOPLE REGARDING VITILIGO
}

\section{Uzma eram}

Department of Community Medicine, J.N.M.C.H, A.M.U., Aligarh

\section{A R T I C L E I N F O}

\section{Article History:}

Received $26^{\text {th }}$ December, 2016

Received in revised form $18^{\text {th }}$ January, 2017

Accepted $14^{\text {th }}$ February, 2017

Published online $28^{\text {th }}$ March, 2017

\section{Key words:}

Vitiligo, Myths, Beliefs \begin{abstract}
A B S T R A C T
Vitiligo is a chronic noncontagious skin disease that causes depigmentation.It affects approximately 1 to $2 \%$ of the total population of the world. The people may suffer related social and emotional consequences.Most vitiligo patients report feeling embarrassed,which can lead to low self-esteem and social isolation. For many centuries, people with vitiligo were not allowed to get jobs and were kept away from getting married and were uninvited to marriages because their old ancient and religious beliefs.Vitiligo was referred to as 'Kilas' in rigvedas, which means Deer like skin. Vitiligo is an acquired depigmentation disorder of great concern affecting 1-4\% of the world population. Educating the public about vitiligo could lead to increased self-confidence, better social integration, and psychological well-being for vitiligo patients. The community health workers should give proper health education to people.Separate skin clinic should be opened at the centres and skin specialists should be there at the clinics.
\end{abstract}

Copyright $@ 2017$ Uzma eram. This is an open access article distributed under the Creative Commons Attribution License, which permits unrestricted use, distribution, and reproduction in any medium, provided the original work is properly cited.

\section{INTRODUCTION}

Vitiligo is a chronic noncontagious skin disease that causes depigmentation (1). It affects approximately 1 to $2 \%$ of the total population of the world $(2,3)$. It represents a heavy burden for the patients' quality of life $(4,5)$. The people may suffer related social and emotional consequences (6). Most vitiligo patients report feeling embarrassed, which can lead to low self-esteem and social isolation (7). Some of the students with vitiligo withdraw from schools due to frequent doctor visits and the taunting they experienced at school (10). Vitiligo was also noted to be a barrier to marriage (11). For many centuries, people with vitiligo (12) were not allowed to get jobs and were kept away from getting married and were uninvited to marriages because their old ancient and religious beliefs.Vitiligo was referred to as 'Kilas' in rigvedas, which means Deer like skin(13). Vitiligo is an acquired depigmentation disorder of great concern affecting $1-4 \%$ of the world population (15-19).

\section{Review of Literature}

A study (8) was conducted in Riyadh, Saudi Arabia, between January and August 2010.It was reported that more than half of the participants $(58.2 \%, 523$ of 899$)$ would sympathize with vitiligo patients. More than half of the participants $(56.1 \%)$ would not accept marriage to a vitiligo patient, $19.3 \%$ would decide after consulting a doctor, $13.8 \%$ would

*Corresponding author: Uzma eram

Department of Community Medicine, J.N.M.C.H, A.M.U., Aligarh accept only if the vitiliginous patches werein hidden areas (meaning not on the face or hands), and 10.8\% would accept regardless of the location of the vitiliginous patches. Females and those with lowerincome were more frequently willing to marry a vitiligo patient than were males or those with a higher income.Younger individuals would refuse marrying a vitiligo patient more often than older ones. Another study (9) from Central India reported that $6.6 \%$ of participants thought vitiligo to be a lethal disease. $55.7 \%$ in the study had belief in probable complete cure by using alternative (homeopathic or Ayurvedic) medicines while (51.7\%) had belief in the efficacy of allopathy treatment. (21.7\%) believed that there is no effective treatment, $(18.6 \%)$ even thought that the treatment might further aggravate the disease. A total of $(23.0 \%)$ participants had witnessed marital difficulties for vitiligo affected persons. Discrimination at the workplace was also reported by a large number $(28.3 \%)$ of participants. The causes assumed by the participants in that study included autoimmunity $(41.2 \%)$, heredity $(40.50 \%)$, diet $(30.50 \%)$, poor hygiene $(22.5 \%)$, and evil eye $(29.3 \%)$. $69.14 \%$ of participants were unwilling to marry a vitiligo patient even when he or she was otherwise a suitable match.

Another study (10) in India reported that the disease was not considered contagious, heritable or related to leprosy by most patients. Vitiligo was considered a serious illness because of possible adverse effects on marriage and securing a job, the undesirable appearance, stigma, the lack of response to treatment, and the burning sensation on sun exposure. Dietary restrictions were frequently kept. Various foods were avoided such as sour items, non-vegetarian food, milk/curd, excess 
masala/ chilli, alcohol, oil, food that was not home-cooked, sweets, rice, tea, wheat chapattis, green vegetables, a combination of non-vegetarian food and milk and salt on Sunday. Other restrictions that were undertaken included the wearing of synthetic and cotton clothes and plastic or rubber shoes. Patients wore clothes that covered their vitiligo. Patients were unhappy with the way they now looked. The disease was a cause for worry, depression and low selfesteem. This worry lessened as time went by and they came to accept it. A few patients admitted to having had suicidal thoughts at times, but none had attempted suicide. Some patients thought about their vitiligo all day, some whenever they looked in the mirror and some not at all. Occasional problems faced in school or college were difficulty in participation in competitions in school, preferring a correspondence course to a regular course in college, having to leave school due to continuous visits to the doctors and being teased in school by other students. Problems were uncommon at the workplace. A few people had difficulty in getting a job and were not allowed to join the careers of their choice including, defence services, civil services, air force, and courier services. Unmarried patients anticipated difficulties in getting married, women more than men.One patient had been rejected by her in-laws and told to get divorced if not cured. A few patients who had vitiligo on the exposed areas had stopped attending social functions and meeting people as they were ashamed of their disease. They were teased by children and avoided shaking hands with other people. They had difficulty with or were tired of answering queries. One man was abused as a leper and cast out of his village. One patient did not visit his sister as he thought she would be ostracized by her in-laws if they discovered she had a brother with vitiligo. Two patients, one male and one female had been told to live separately from their spouses and another was separated from her brothers and sisters because her parents thought vitiligo was contagious. Patients had sought alternative medicine and visited homeopaths,

Ayurvedic doctors and practitioners of other systems of indigenous medicine in the past. These were believed not to cause side effects. In a few cases, the vitiligo had been mistaken and treated for leprosy.Vitiligo also causes a financial burden. Different types of coping mechanisms were used when patients thought about their disease. Patients resorted to praying to God or distracted their mind with music, television, books, playing games or doing their work. Other mechanisms were talking to their family members, friends or doctor or trying to find a cure by reading books. Patients with poor coping mechanisms expressed emotional reactions in the form of crying, avoiding company, were constantly preoccupied with the disease, took alcohol daily to forget and had suicidal thoughts.

A study in Nigeria (14) reported that twenty six percent of responders think that vitiligo was caused by an infection of some sort, while $17.3 \%$ thinks it is inherited. Social outings were reduced in $41 \%$ of affected people. Ninety percent of the people were embarrassed by their own lesions. Derogatory names by which they were called included "leopard skin", "boy with the white nose", "multicoloured", "Rainbow". People refused sitting next to them, avoided shaking hands and eating around them. Cosmetic cover-up was used especially by females affected. These included gentian violet, lipsticks, brown powder, charcoal and black eyebrow pencils.
No patient had intent to commit suicide. Relationships were well preserved in the 37 married people with vitiligo. The vitiligo did not affect their sexual relationships and there was no increase in the number of quarrels, disagreements and separation among couples.

\section{CONCLUSION}

Mass public education campaigns should be organized to remove the misconceptions regarding vitiligo prevalent in our society.Most people have common negative attitudes and misunderstandings about vitiligo. E.g. it is contagious or that it is caused by poor hygiene. Educating the public about vitiligo could lead to increased self-confidence, better social integration, and psychological well-being for vitiligo patients. The community health workers should give proper health education to people.Separate skin clinic should be opened at the centres and skin specialists should be there at the clinics.

\section{References}

1. Hartmann A, Brocker EB, Becker JC. Hypopigmentary skin disorders: current treatment options and future directions. Drugs 2004; 64:89-107, doi:10.2165/00003495-200464010-00006.

2. El-Zawahry M. Pigmentary dermatoses. In: Lerner $\mathrm{AB}$, editor. Skin diseases in Arabian countries. Cairo: French Institute of Oriental Archeology; 1964. p. 5572.

3. Mosher DB, Fitzpatrick TB, Ortonne JP. Disorder of pigmentation: vitiligo. In: Fitzpatrick TB, Eisen AZ, Wolff $\mathrm{K}$, et al, editors. Dermatology in general medicine. 1st ed. New York: McGraw-Hill;1993. p. 903-95.

4. Schmid-Ott $\mathrm{G}, \mathrm{Ku}$ "nsebeck HW, Jecht E, et al. Stigmatization experience,coping and sense of coherence in vitiligo patients. J Eur Acad Dermatol Venereol 2007; 21: 456-61.

5. Sampogna F, Raskovic D, Guerra L, et al. Identification of categories at risk for high quality of life impairment in patients with vitiligo. $\mathrm{Br} J$ Dermatol 2008; 159: 351-9, doi:10.1111/j.13652133.2008.08678.x.

6. Walker C, Papadopoulos L. Psychodermatology. New York: Cambridge University Press; 2005.

7. Talsania N, Lamb B, Bewley A. Vitiligo is more than skin deep: a survey of members of the Vitiligo Society. Clin Exp Dermatol 2010; 35: 736-9, doi: 10.1111/j .1365-2230.2009.03765.x.

8. Khalid M. AlGhamdi, Noura A. Moussa, Ahmed Mandil, et al. Public Perceptions and Attitudes Toward Vitiligo. Journal of Cutaneous Medicine and Surgery, Vol 16, No 5 (September/October), 2012: pp 334-340.

9. Dinesh Prasad Asati, C. M. Gupta, Shreyansh Tiwari, Sanjeev Kumar, Vishal Jamra. A hospital-based study on knowledge and attitude related to vitiligo among adults visiting a tertiary health facility of central India. Journal of Nat Sc Biol Med; 2016; 7:27-32.

10. Pahwa P, Mehta M, Khaitan BK, Sharma VK, Ramam M. The psychosocial impact of vitiligo in Indian patients. Indian J Dermatol Venereol Leprol. 2013; 79 (5):679-685. 
11. Thompson AR, Clarke SA, Newell RJ, Gawkrodger DJ; Appearance Research Collaboration. Vitiligo linked to stigmatization in British South Asian women: a qualitative study of the experiences of living with vitiligo. $\mathrm{Br} J$ Dermatol. 2010; 163 (3):481-486

12. Lesley $\mathrm{M}$, et al.Vitiligo: A comprehensive overview. Journal of the American Academy of Dermatology. 2011;65:493-514

13. Cunha PR and Kroumpouzos G.Melasma and Vitiligo: Novel and Experimental Therapies. J Clin Exp Dermatol Res. 2016;7:e106

14. O. A. Olasode, A. O. George, Femi Soyinka. Psychosocial problems in patients with vitiligo in Nigeria. Sudan J Dermatol 2007; Vol 5 (2) : 51 -58
15. Lerner AB: Vitiligo. J Invest Dermatol 1959, 32:285310.

16. Lerner $\mathrm{AB}$ and Nordlund JJ: Vitiligo. What is it? Is it important? JAMA1978, 239:1183-1187.

17. Bolognia JL and Pawelek JM: Biology of hypopigmentation. J Am Acad Dermatol 1988, 19:217-255.

18. Handa S and Kaur I: Vitiligo: clinical findings in 1436 patients. J Dermatol 1999, 26:653-657.

19. Handa S and Dogra S: Epidemiology of childhood vitiligo: a study of 625 patients from North India. Ped Dermatol 2003,20:207-210

\section{Please cite this article in press as:}

Uzma eram (2017), Review Article On Beliefs And Myths Of People Regarding Vitiligo, International Journal of Current Advanced Research, 6(3), pp. 2808-2810. http://dx.doi.org/10.24327/ijcar.2017.2810.0111 